Volume 4 Nomor 2 Oktober 2020

e-ISSN: 2549-9114 dan p-ISSN: 2549-9203

(Received: Februari-2020; Reviewed: Agustus-2020; Published: Oktober-2020)

https://doi.org/10.26858/pembelajar.v4i2.13126

\title{
Kemampuan Menspesifikasi Topik Sebagai Bentuk Perwujudan Keterampilan Menulis Esai
}

\author{
Tresiana Sari Diah Utami ${ }^{1}$, Katarina Retno Triwidayati ${ }^{2}$, Maria Angelina Priyanti ${ }^{3}$ \\ ${ }^{1}$ Universitas Katolik Musi Charitas \\ ${ }^{2}$ Universitas Katolik Musi Charitas \\ ${ }^{3}$ Universitas Katolik Musi Charitas
}

Corresponding e-mail : tresiana@ukmc.ac.id, retno@ukmc.ac.id, angelinapriyanti@gmail.com

Abstrak: Tulisan esai memiliki ciri memfokuskan pembahasan akan satu hal. Fokus masalah yang dipilih dibahas secara luas dan menyeluruh. Penelitian ini merupakan penelitian kualitatif yang dilaksanakan pada tahun pelajaran 2018/2019 dan didanai oleh Kemenristekdikti dengan skema Penelitian Dosen Pemula pada tahun 2019. Penelitian ini dilaksanakan di Universitas Katolik Musi Charitas dengan jumlah populasi sebanyak 382 tulisan dan sampel ditentukan sebanyak 180 tulisan secara acak. Penelitian dilaksanakan dengan pen and paper based teks, yaitu memberikan teks menulis pada mahasiswa yang diteliti. Mahasiswa yang diteliti diminta membaca teks berita yang telah ditentukan, menganalisis topik yang terdapat pada berita tersebut, kemudian menulis teks esai sederhana berdasarkan hasil analisisnya. Hasil tulisan mahasiswa tersebut kemudian dinilai oleh dua orang dan nilai akhir ditentukan dengan menghitung rerata dari nilai kedua penilai tersebut. Makalah ini membahas kemampuan mahasiswa dalam menulis dispesifikkan pada karakter esai yang merupakan reaksi atau pernyataan pandangan seseorang terhadap topik yang dibahas. Oleh sebab itu, teks yang diharapkan hanya fokus pada satu topik dari beberapa topik yang dipaparkan dalam teks utama (berita). Hasil penelitian menunjukkan 79.4\% mahasiswa yang diteliti belum mampu menulis esai yang memiliki satu topik tunggal. Mahasiswa masih memaparkan topik-topik yang terdapat pada teks pertama dan tidak memperkuat argumentasinya dengan bukti namun hanya sekedar memaparkan topik di teks pertama. Hanya terdapat $12.2 \%$ mahasiswa yang mampu menulis teks esai yang memaparkan satu topik dan melengkapinya dengan argumentasi dan bukti pendukung.

Kata Kunci: teks berita, spesifikasi, esai.

Abstract: Essay writing has the characteristic of focusing the discussion on one thing. The focus of the problem chosen is discussed widely and thoroughly. This research is a qualitative study conducted in the 2018/2019 academic year and funded by the Ministry of Research and Technology with the Beginner Lecturer Research scheme in 2019. The research was conducted at Musi Charitas Catholic University with a population of 382 writings and a sample of 180 random samples. The study was conducted with pen and paper based text, which provides writing texts to students studied. The students studied were asked to read the predetermined news text, analyze the topics contained in the news, then write a simple essay text based on the results of the analysis. The student's writing is then assessed by two people and the final grade is determined by calculating the average of the scores of the two assessors. This paper discusses the ability of students in writing specified on the character of the essay which is a reaction or statement of one's views on the topic discussed. Therefore, the expected text only focuses on one topic from a number of topics presented in the main text (news). The results showed $79.4 \%$ of students studied were not able to write essays that had one single topic. Students still explain the topics contained in the first text and do not strengthen their argument with evidence, but only explain the topics in the first text. There are only $12.2 \%$ of students who are able to write essay texts that describe one topic and complete it with supporting arguments and evidence.

Keywords: news texts, specifications, essays. 


\section{PENDAHULUAN}

Menulis merupakan salah satu keterampilan berbahasa. Dari keempat keterampilan bahasa antara lain menyimak, berbicara, dan membaca, menulis dianggap sebagai kemampuan yang paling kompleks dikarenakan menulis dijadikan keterampilan paling akhir setelah keterampilan menyimak, berbicara dan membaca.

Keterampilan menulis berfungsi sebagai alat penyampaian informasi secara tidak langsung. Informasi secara tidak langsung tersbut berisi pesan dengan menggunakan alat tulissebagai alat tulis atau medianya. Dalam kegiatan menulis juga, penulis mengungkapkan gagasan berupa lambang-lambang grafis yang menggambarkan suatu bahasa yang dipahami oleh seseorang secara sistematis (Dalman, 2014:1).

Byrne menyatakan bahwa menulis bukan sesuatu yang diperoleh secara spontan, melainkan kegiatan yang memerlukan usaha sadar "menuliskan" kalimat dan mempertimbangkan cara mengkomunikasikan dan mengatur (Herni Yamasitha, Sisilya Saman, Martono, 2015).

Oleh sebab itu, kegiatan menulis dianggap kegiatan yang masih sulit untuk dilaksanakan. Hal tersebut dapat dilihat dari masih banyaknya plagiasi yang terjadi di Indonesia.

Plagiasi terjadi salah satunya dikarenakan kurangnya informasi yang dimiliki atau kurangnya informasi penting yang dimiliki oleh penulis. Akibatnya, penulis menulis ulang informasi yang diperoleh tanpa memparafrasekan informsai tersebut. parahnya lagi, penulis dengan berani tidak mencantumkan sumber informasi awal.

Hasil survei Programme for International Student Assessment (PISA) menunjukkan bahwa pada tahun 2006 Indonesia berada di peringkat 50 dari 57 negara yang disurvei. Pada tahun 2009, Indonesia berada di posisi 60 dari 65 negara yang berpartisipasi dan pada survei tahun 2012 Indonesia berada di posisi 64 dari 65 negara yang berpartisipasi (Wulandari, www.jurnal.uinjkt.ac.id, diunduh pada tanggal 20 Maret 2019, pada pukul 16.00 WIB). Sedangkan pada tahun 2015 Indonesia berada diperingkat 64 dari 65 negara yang disurvei (Permatasari, www.repository.unib.ac.id, diunduh pada tanggal 30 Maret 2019, pada pukul 20.11 WIB).
Survei PISA yang dilakukan pada tingkat pendidikan dasar tersebut dapat menjadi acuan bahwa budaya literasi di sekolah dasar di Indonesia masih rendah. Salah satu penyebab rendahnya tingkat literasi yaitu pendekatan yang jarang atau bahkan tidak digunakan dengan tepat oleh pendidik.

Banyak metode maupun pendekatan yang dapat dilakukan dalam pembelajaran bahasa khususnya menulis. Pendekatan dalam pembelajaran bahasa yang dapat digunakan salah satunya adalah pendekatan berbasis teks/ genre based appoach.

Genre-based approach sebagai suatu pendekatan dalam pembelajaran bahasa dengan menambah penguasaan akan berbagai jenis teks. Dengan menguasai berbagai jenis teks, kegiatan menulis diharapkan akan lebih baik dibandingkan sebelumnya. Dalam melaksanakan pendekatan genre-based approach, pendidik dapat menerapkan metode pembelajaran menulis yaitu metode menulis berbasis genre (genre based writing).

$$
\text { Macken (Abidin, 2017:220) }
$$
mengemukakan bahwa, Metode menulis berbasis genre (genre based writing) merupakan metode pembelajaran menulis yang menekankan pada pentingnya pemahaman sebuah teks sebagai bekal kegiatan menulis.

Berdasarkan pendapat di atas, metode tersebut pendidik akan membekali peserta didik mengenai sebuah tulisan bergenre tertentu dengan tetapi dengan membekali sebuah contoh atau model sebuah tulisan yang sudah jadi. Metode pembelajaran menulis tersebut sering disebut dengan mengonversi teks.

Dalam hal ini, peserta didik akan menuliskan atau menghasilkan sebuah teks baru setelah melakukan kegiatan membaca teks yang tepat. Teks yang terbentuk merupakan sebuah produk atau tulisan yang berasal dari kegiatan memabaca sebuah tulisan bergenre tertentu.

Teks yang dijadikan sebagai model tulisan dapat berupa genre tertentu, salah satunya teks berita. Teks berita yang baik dapat menjawab pertanyaan dengan bantuan kata tanya $5 \mathrm{~W}+1 \mathrm{H}$. Teks berita memberikan banyak informasi dari jawaban atas pertanyaan-pertanyaan tersebut.

Esai dapat dikatakan sebagai prosa yang mebahas sebuah masalah secara sepintas lalu. Esai dapat pula diartikan sebagai tulisan yang lebih dari satu paragraf tetapi berisi satu topik yang dibahas. Topik yang dibahas dalam esai tersebut harus dikupas atau dibahas secara luas dan lengkap.

Dalam mengoversi teks,teks berita dapat dijadikan sebagai model atau contoh tulisan 
yang tepat. Teks berita berisi informasi yang dapat digali oleh penulis atau peserta didik. Teks berita yang memiliki banyak informasi dapat dikonversikan menjadi teks esai.

Secara umum, esai yang baik selalu fokus pada satu tema atau satu topik tertentu. Dalam hal mengubah satu teks berita menjadi teks esai, seorang penulis dianggap berhasil apabila bisa mengambil inti dari teks bacaan yang telah dibacanya yang kemudian mulai menulis dengan tetap fokus pada satu topik yang ditentukan dan mereduksi informasi dari teks pertama.

Universitas Katolik Musi Charitas merupakan salah satu universitas di Kota Palembang. Di universitas ini, pembelajaran bahasa ditemou oleh mahasiswa baru semester 1 dan 2 yang notabenenya sudah mempelajari tentang teks berita dan penulisan karya tulis ilmiah, salah satunya esai. Berdasarkan latar belakang di atas, artikel ini akan membahas mengenai kemampuan mahasiswa Universitas Katolik Musi Charitas dalam mengonversi teks.

\section{METODE}

Penelitian ini menggunakan metode deskriptif. Penelitian dengan metode deskriptif adalah suatu bentuk penelitian yang paling dasar yang ditujukan untuk mendeskripsikan atau menggambarkan fenomena-fenomena yang ada, baik fenomena yang bersifat alamiah ataupun rekayasa manusia. Begitu juga dengan pendekatan, pendekatan yang digunakan dalam penelitian ini bersifat kualitatif. Penelitian kualitatif ditujukan untuk memahami fenomenafenomena sosial dari sudut atau perspektif partisipan (Sukmadinata, 2016).

Penelitian ini dilakukan di Universitas Katolik Musi Charitas. Subyek penelitian ini adalah mahasiswa Universitas Katolik Musi Charitas di tiga fakultas dan dua belas prodi.

Jumlah populasi sebanyak 382 mahasiswa. Dari populasi tersebut, sample penelitian ditentukan berdasarkan teori kemungkinankemungkinan penuntuan sample yang dikemukakan oleh Sugiyono (2018:302) antara lain jenis kelamin, jumlah prodi, dan kategori mahasiswa yang mengambil makul Bahasa Indonesia.

Berdasarkan kemungkinan-kemungkinan yang dikemukakan didapatkan 180 mahasiswa yang menjadi sample penelitian. Sample penelitian diambil secara random di tiap prodinya.

Teknik pengumpulan data yang digunakan pada penelitian ini adalah dengan pen and paper based teks, yaitu memberikan teks menulis pada mahasiswa yang diteliti. Mahasiswa yang diteliti diminta membaca teks berita yang telah ditentukan, menganalisis topik yang terdapat pada berita tersebut, kemudian menulis teks esai sederhana berdasarkan hasil analisisnya.
Teknik analisis data adalah proses mengatur urutan data, mengorganisasikannya ke dalam suatu pola, kategori, dan satuan uraian dasar (Afifuddin dan Saebani, 2009:145). Pada kegiatan analisis data ini, peneliti perlu melakukan pengorganisasian data, menguji asumsi atau permasalahan yang ada terhadap data, mencari alternatif penjelasan bagi data.

Penelitian ini menggunakan validasi dengan modus triangulasi peneliti. Triangulasi peneliti pada penelitian ini yaitu dengan bantuan dua orang penilai yang menilai hasil tulisan mahasiswa. Hasil penilaiannya nanti akan dipersentasekan untuk mengetahui banyak mahasiswa yang tulisannya fokus pada satu topik.

\section{HASIL DAN PEMBAHASAN}

Universitas Katolik Musi Charitas adalah Universitas yang terdiri dari empat fakultas, yaitu Fakultas Bisnis dan Akuntansi, Fakultas Sains dan Teknologi, Fakultas Humaniora dan Ilmu Pendidikan, dan Fakultas Ilmu Kesehatan. Sebagaimana yang dijelaskan pada metodologi penelitian, subyek penelitian ini adalah mahasiswa Universitas Katolik Musi Charitas yang mengampu mata kuliah Bahasa Indonesia dengan jumlah sample sebanyak 180 mahasiswa yang berarti 180 tulisan yang dihasilkan mahasiswa.

Penelitian dimulai dengan meminta mahasiswa untuk membaca teks berita yang telah ditentukan. Selanjtnya, mahasiswa diminta menuliskan teks esai sebanyak tiga paragraf saja, tanpa menginformasikan bentuk, struktur, dan isi topik dari teks berita yang telah dibaca.

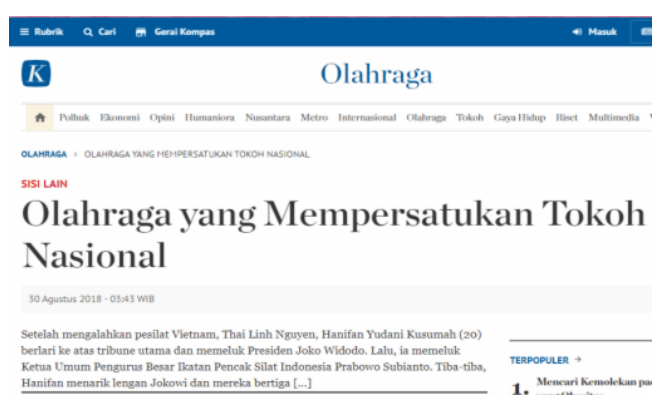

Teks berita yang dipilih adalah teks berita yang dipublikasikan oleh kompas, pada hari Kamis, 30 Agustus 2018.

Berita tersebut menginformasikan mengenai kemenangan Hanifan, atlet pencak silat mengalahkan atlet pencak silat dari Vietnam. Selebrasi yang dilakukan oleh Hanifan membuat masyarakat bahagia yaitu dengan memeluk Jokowi dan Prabowo, padahal saat itu masih dalam masa tegang dalam pemilihan Presiden RI periode 2019/2024.

Artikel ini hanya memfokuskan dalam kemampuan mahasiswa Universitas Katolik Musi Charitas dalam penentuan topik atau 
spesifikasi topik dalam tulisan esai. Berdasarkan hasil penelitian didapatkan hasil sesuai dengan diagram 1. Berikut disajikan diagram 1 ,

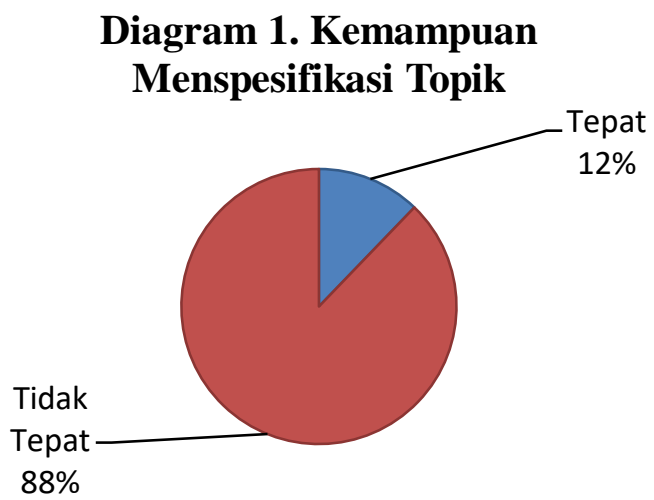

Berdasarkan diagram 1, sebanyak $12 \%$ tulisan mahasiswa yang diteliti mampu menspesifikasi topik dalam penulisan esai. Sedangkan sebanyak $88 \%$ mahasiswa yang diteliti belum mampu menulis esai dengan tepat dan masih menuliskan beberapa topik dalam esai.

\section{PEMBAHASAN}

Berdasarkan hasil penelitian, sebanyak $12 \%$ tulisan mahasiswa yang diteliti mampu menspesifikasi topik dalam penulisan esai. Sedangkan sebanyak $88 \%$ mahasiswa yang diteliti belum mampu menulis esai dengan tepat dan masih menuliskan beberapa topik dalam esai. Hal tersebut dapat disebabkan dua hal, antara lain tidak memahami konsep esai dan tanpa melewati tahapan menulis dengan tepat.

\section{Penyebab}

Sebanyak $88 \%$ tulisan yang dihasilkan oleh mahasiswa Universitas Katolik Musi Charitas memiliki lebih dari satu topik yang dibahas. Tiga paragraf yang ditulis oleh mahasiswa bahkan ada berisi tiga topik yang berbeda. Hal ini menunjukkan bahwa mahasiswa belum memahami konsep dari tulisan esai.

Dalam teks berita yang dibaca oleh mahasiswa, terdapat beberapa topik yang dapat diperluas menjadi esai. Topik tersebut antara lain, pertama kalinya pencak silat ditandingkan dalam ASEAN Games, kemenangan Hanifan mengalahkan atlet pencak silat Vietnam, atau kekompakan Prabowo dan Jokowi di ASEAN Games. Namun, hanya beberapa yang mampu menuliskan esai dengan memilih fokus dengan satu topik saja. Banyak tulisan yang dihasilkan yang lebih dari satu topik yang dibahas. Berikut disajikan tulisan tersebut,

\section{Hanifan Memeluk Jokowi dan Prabowo}

Ketika hanifan Yudani
Kesumah menang melawan
Vietnam diajang pertandingan
pencak silat. Hanifan memeluk
kedua tokoh politik yang sedang
bersaing dalam pemilihan Presiden
periode 2019-2014 momen
tersebut langsung disambut meriah
oleh penonton yang ada di
padepokan pencak silat TMII,
Jakarta Timur.
Peristiwa tersebut langsung
heboh di media nasional dan
mendapat respon postitif dari
masyarakat dan warganet serta
menjadi momen yang
membanggakan karena terlihat 2
kubu yang sebelumnya panas
menjadi teduh.
Asiang olahraga terbesar se
Asia yaitu Asian Games bis
mempersatukan bangsa dan
memperkompak masyarakat dalam
mendukung Indonesia tanpa harus
memikirkan kepentingan sendiri
yang penting semuanya hanya
untuk Indonesia.

Berdasarkan tulisan di atas, topik masalah yang dibahas berbeda-beda tiap paragraf. Topik paragraf pertama membahas mengenai kemenangan Hanifan. Paragraf kedua membahas Politik yang disatukan oleh pencak silat. paragraf ketiga membahas pencak silat dalam Asean Games.

Kurangnya pemahaman mahasiswa mengenai konsep paragraf membuat keberagaman topik yang dibahas. Pemahaman mereka mengenai esai terbatas dalam karangan argumentatif saja. Esai memang berisi argumen penulis. Namun, Nugrahaeni (20117:142) mengemukakan bahwa esai berisi beberapa paragraf mengenai satu topik. Dalam esai, penulis mengemukakan pendapat. Jadi, topik atau permasalahan yang dibahas oleh penulis harus satu tidak lebih.

Selain kurangnya pemahaman bahwa esai harus berisi satu topik yang dibahas, struktur esai yang harusnya terdiri dari pembuka, isi , dan penutup juga masih belum dipahami oleh mahasiswa. Tulisan yang dihasilkan masih berstruktur isi saja tanpa memperhatikan pembuka dan penutup. Segingga esai yang ditulis juga bahkan hanya mengulang teks berita yang dibaca sebelumnya. Berikut disajikan tulisan yang dihasilkan oleh mahasiswa, 


\section{Olahraga yang Mempersatukan Tokoh Nasional}

Rabu, tim pencak silat mengukir sejarah besar dengan mempersembahkan 14 medali emas bagi Indonesia. cabang ini baru pertama kali dipertandingkan di Asian Games. Salah satu atlet yaitu Hanifan Yudani Kusumah yang berumur 20 tahun berhasil mengalahkan pesilat dari Vietnam yaitu Thai Linh Nguyan. Hanifan berlari ke atas tribune utama dan langsung memeluk Presiden Joko Widodo dan ia juga memeluk Ketua Umum Penurus Ikatan Pencak Silat Indonesia Prabowo Subianto. Dan ia juga menarik lengan Jokowi dan mereka bertiga berpelukan. Sang juara dan dua tokoh yang akan bersaing pada pemilihan Presiden 2019 itu saling tersenyum dan menempelkan kepala sekitar 5 detik. Momen langka itu juga di sambut tepuk tangan dan riuh oleh penonton yang memadati Padepokan Pencak Silat Tman Mini Indonesia Indah.

Hanifan pun mengaku bahwa peristiwa itu terjadi secara spontan. Kebetulan Hanifan mendapati Jokowi dan Prabowo sekaligus dan ia juga menyelimuti tubuhnya dengan bendera merah putih. "Saya hanya ingin melalui pencak silat, bangsa ini bisa bersatu. Terutama karena pencak silat adalah budaya bangsa" kata Hanifan setelah momen pelukan bersama dua tokoh itu. Momen itu secara visual memiliki makna sangat mendalam. Foto pelukan itu juga menjadi viral di jagat maya dan mendapat. tanggapan positif dari warganet. Ketika laga itu berakhir dan para tamu beranjak pulang, Jokowi, Prabowo dan Megawati Juga bercanda di hadapan media "Saya dan Pak Prabowo tidak tahu, kok, diajak pelukan barengan. Tapi yang Jelas bau-baunya harum karena menang" kata Jokowi saat ditanya mengenai momen tersebut.

Jokowi Juga mengucapkan terima kasih kepada Prabowo yang telah bekerja keras mengembangkan pencak silat. Prabowo dan Megawati pun sempat bercanda. Sore itu, Prabowo tambak gembira karena semua tokoh penting hadir di saat-saat kritis untuk membangkitkan semangat masyarakat. kalau sudah untuk negara dan bangsa, kita semua bersatu dan tidak ada perbedaan "ujar Prabowo. Wakil Presiden Juga menyatakan Asian Games tidak hanya mempersatukan masyarakat, tetapi Juga para tokoh politik. Jadi, Asian Games ini momen masyarakat Indonesia bersatu, semua orang bersatu.

Berdasarkan tulisan di atas, esai yang dihasilkan masih belum memiliki struktur pembangun esai yang tepat. Esai yang ditulis tidak berstruktur pembuka, isi, dan penutup.

Esai yang ditulis masih berstruktur isi saja. Isi yang dibahas meliputi Asean Games, Jokowi dan Prabowo, serta kebanggaan masyarakat akan kemenangan dan bersatunya kedua tokoh. Pembuka dan penutup esai diabaikan oleh penulis.

Hidayah (https://osf.io, diunduh pada tanggal 6 November 2019, pada pukul 15.15 WIB) mengemukakan bahwa esai terdiri dari tiga bagian. Bagian pertama adalah pendahuluan yang berisi latar belakang informasi singkat mengenai topik yang akan dibahas. Paragraf selanjutnya berisi isi atau inti esai, inti dari pembahasan dibahas dalam paragraf ini. Paragraf terakhir berisi penutup yang membahas simpulan dari pembahasan esai.

Selain itu, mahasiswa masih menyalin ulang teks berita yang dibaca. Hal ini terlihat struktur berita yang masih nampak dalam esai yang dihasilkan. Mahasiswa masih menuliskan kembali informasi $5 \mathrm{~W}+1 \mathrm{H}$ yang ia peroleh sebelumnya. Seharusnya, dari informasi $5 \mathrm{~W}+1 \mathrm{H}$, mereka mampu menarik ide pokok atau memilih informasi yang akan dibahasnya. Ide-ide pokok yang didapatkan dari kegiatan menganalisis $5 \mathrm{~W}+1 \mathrm{H}$ itulah yang harusnya dipilih dan diubah menjadi bentuk teks kedua dengan fokus pada satu topik dan dibantu dengan argumen-argumen yang dibuat sendiri sebagai pendukung.

Penyebab selanjutnya dikarenakan menulis tanpa melewati tahapan menulis dengan tepat. Tahapan menulis yang tepat antara lain pramenulis, menulis, dan pascamenulis. Hal ini senada dengan pendapat Dibia (2016:127-132) bahwa dalam menulis terdapat tiga tahapan antara lain, tahap persiapan, penulisan, dan penyuntingan.

Tahap persiapan dilakukan bertujuan menemukan masalah yang akan dibahas. Persiapan yang dapat dilakukan dalam mengonversi teks berita menjadi esai dapat melalui informasi $5 \mathrm{~W}+1 \mathrm{H}$.

Tahap menulis dilakukan untuk mengembangkan konsep awal informasi yang diperoleh. Informasi yang sudah ditentukan akan ditulis dibahas secara rinci dan detail.

Tahap terakhir, tahap penyuntingan. Menyunting tulisan menjadi bagian dalam 
menulis. Penyuntingan esai dapat dilakukan dalam memeprbaiki ejaan atau tanda baca, unsur kebahasaan, struktur esai, hingga spesifikasi atau ketepatan topik yang dipilih. Tahap penyuntingan.

Nirmawan

(https://media.neliti.com/, diunduh pada tanggal 7 November 2019, pada pukul 10.10 WIB) mengemukakan pendapat bahwa selain struktur kebahasaan, penyuntingan dilakukan untuk memperhatikan ejaan, tanda baca, pilihan kata, keefektifan kalimat dan ketepatan paragraf sehingga memperoleh suntingan yang baik. Penyuntingan dilakukan untuk mendapatkan tulisan yang baik dan benar secara ketatabahasaan dan bernalar.

Lanjutnya, penyunting yang baik harus mampu melihat teks tulisan yang benar, kohesi, dan koherensi yang tepat. Setelah tahap penyuntingan dilakukan, penulis akan menghasilkan tulisan yang baik.

\section{Solusi yang Ditawarkan}

Penyebab-penyebab terjadinya kesalahan dalam penulisan esai dapat diperbaiki melalui pendekatan pembelajaran menulis dengan tepat. Penyebab terbesar terjadinya kesalahan karena pembiaran yang dilakukan pendidik sebelumnya.

Berdasarkan hasil penelitian yang dilakukan oleh Lie, dkk (2018) bahwa dari keenam kota yang tersebar di Indonesia, guruguru bahasa dalam hal ini Bahasa Indonesia dan Bahasa Inggris memiliki kompetensi menulis yang masih di bawah standar. Dalam bidang Bahasa Indonesia, hasil penelitian menunjukkan bahwa, Hasil tes menulis guru SMP: nilai terendah 5,5 dan nilai tertinggi 100. Sejumlah 47,5\% guru SMP mampu mengerjakan soal atau memiliki tingkat pemahaman bacaan yang cukup. Sedangkan guru bahasa Indonesia tingkat SMA, sejumlah $65 \%$ mampu mengerjakan soal atau memiliki tingkat pemahaman bacaan yang cukup. Dengan demikian dapat dinyatakan bahwa tingkat pemahaman bacaan yang berada pada kategori cukup sebesar $56,2 \%$ dari total guru yang diteliti. Sedangkan 43,8 guru bahasa Indonesia tingkat SMP dan SMA yang diteliti tingkat pemahaman bacaannya kurang.

Tidak heran, jika dengan tingkat pemahaman di bawah $60 \%$ agak sulit bagi pendidik untuk menginformasikan atau melakukan pembelajaran menulis dengan tepat. Salah satu solusi yang dapat dilakukan adalah guru melakukan pembelajarn menulis dengan menggunakan konsep pembelajaran dasar literasi menulis.

Pembelajaran dasar literasi menulis berbeda dengan pembelajaran menulis pada umunya. Pembelajaran literasi menulis menuntut peserta didik melakukan proses menulis secara berulang-ulang untuk merevisi ide-idenya, mengulangi setiap proses kegiatan menulis sehingga mampu mengaplikasikan kemampuan menulis secara maksimal.

Secara umum, pembelajaran literasi menulis memiliki tahapan yang sama dengan tahapan menulis pada umunya. Hal yang membedakannya, tahapan dalam pembelajaran literasi menulis lebih spesifik dibandingkan kegiatan menulis pada umumnya. Pembelajaran literasi menulis dimulai dari pemerolehan ide, pengolahan ide, pemroduksian ide, penyuntingan, dan publikasi (Abidin, 2017:207-209).

Tahap pertama pemerolehan ide. Dalam tahap ini, peserta didik harus mampu mereaksi berbagai fenomena yang sedang terjadi. Berbagai fenomena dapat diperoleh melalui berbagai hal termasuk keterampilan daya tanggap akan fenomena hidup.

Tahap kedua, pengolahan ide. Dalam tahap ini, peserta didik dituntut menggali ide dengan cara menggali kemampuan berpikir. Kemampuan berpikir diharapkan dapat menghasilkan tulisan yang sesuai dengan nalar, logis, dan memenuhi ciri sebuah tulisan keilmuan.

Tahap ketiga, pemroduksian ide dalam tahap ini, peserta didik harus mampu menggunakan kemampuan memproduksi bahasa yang dimilikinya. Dari kemampuan memroduksi bahasa, peserta didik dituntut mampu mengemas gagasan yang telah diolah sebelumnya. Melalui pengetahuan dan kemampuan mengemas bahasa ini, tujuan kegiatan menulis akan dituju sesuai dengan genre atau tujuan awal penulisan.

Tahap selanjutnya, penyuntingan. Peserta didik akan menilai tulisan yang telah dihasilkan olehnya. Penilaian yang dilakukan dengan memperhatikan isi, kebenaran bahasa, hingga teknik penulisannya. Dalam tahap penyuntingan ini juga, penulis dapat melakukan pembacaan profesional melalui orang lain yang memiliki keilmuan sebidang.

Tahap terakhir adalah publikasi. Dalam tahap publikasi ini, peserta didik dapat mempublikasikan tulisan melalui media, baik media cetak ataupun online.

Dalam proses pembelajaran literasi menulis, peserta didik diharapkan memiliki kemampuan menulis dalam bentuk berbagai genre teks sesuai dengan tujuan, sasaran baca, ataupun konteks keilmuan ataupun sosial budaya. Kemampuan menulis melalui berbagai genre teks didapatkan setelah peserta didik memiliki pengetahuan macam-macam tulisan.

\section{KESIMPULAN}

Berdasarkan uraian hasil penelitian dan pembahasan diatas, dapat disimpulkan bahwa kemampuan menulis esai dalam hal menspesifikasi topik mahasiswa Universitas 
Katolik Musi Charitas masih rendah. Hal ini dibuktikan sedikitnya jumlah penulisan teks mahasiswa dengan fokus pada satu topik pembahasan.

Hasil penelitan menunjukkan dari $100 \%$ hanya $12 \%$ tulisan yang dihasilkan yang berisi satu topik pembahasan. Sisanya, $88 \%$ masih membahas lebih dari satu topik.

Berdarasrkan analisa dari tulisan yang dihasilnya, dua penyebab terlihat dari tulisantulisan tersebut. dua penyebab tersebut adalah tidak memahami konsep esai dan tanpa melewati tahapan menulis dengan tepat.

Dari hasil penelitian diatas, saran yang bisa dilakukan adalah dengan memperbaiki pembelajaran pada jenjang pendidikan baik itu SMP, SMA, maupun Perguruan Tinggi. Pendidik dapat membudayakan membaca dan menulis serta membiasakan menganalisis teks dengan menggunakan $5 \mathrm{~W} \quad 1 \mathrm{H}$ untuk mendapatkan gagasan pokok teks tersebut.

Selain itu, salah satu metode yang dapat dilakukan oleh pendidik agar peserta didik dibekali beberapa jenis tulisan adalah melalui metode genre based teks. Melalui pendekatan tersebut, pendidik dapat mengajarkan berbagai genre tulisan yang dapat dipahami oleh peserta didik.

\section{DAFTAR PUSTAKA}

Affifuddin dan Benii Ahmad Saebani. (2009). Metodologi Penelitian Kualitatif. Bandung: Pustaka Setia.

Dalman. (2014). Menulis Karya Ilmiah. Jakarta: RajaGrafindo.

Dibia, I Ketut dan I Putu Mas Dewantara. (2016). Bahasa Indonesia untuk Perguruan Tinggi. Depok: Rajawali Pers.

Hidayah. (2019). "Panduan Menulis Esai". https://osf.io, diunduh pada tanggal 6 November 2019, pada pukul 15.15 WIB.

Nirmawan. 2017. "Kemampuan Menyunting Karangan Eksposisi Berdasarkan Ejaan, Pilihan Kata, dan Keterpaduan Paragraf Siswa Kelas VII SMP Muhammadiayah 06 Medan Tahun Ajaran 2016-2017". https://media.neliti.com/, diunduh diunduh pada tanggal 7 November 2019, pada pukul 10.10 WIB.

Nugraheni, Ananditya Sri. (2017). Bahasa Indonesia di Perguruan Tinggi Berbasis Pembelajaran Aktif. Jakarta: Prenada Media.

Herni Yamasitha, Sisilya Saman, Martono. (2015). "Menulis Konversi Teks Negosiasi Menjadi Teks". Jurnal Pendidikan dan Pembelajaran , 3.
Lie, Anita, dkk. (2018). "Laporan Pemetaan Kompetensi Guru Bahasa Indonesia dan Bahasa Inggris". Surabaya: Universitas Widya Mandala.

Maulana, N. (2010). "Pendekatan Berbasis Teks (A text-based Approach)" https://najmimaulana.wordpress.com/, diunduh pada tanggal 10 Mei 2019. pada pukul $22.30 \mathrm{WIB}$.

Permatasari, Ane. (2015). "Membangun Kualitas Bangsa Dengan Budaya Literasi”. $\quad$ www.repository.unib.ac.id, diunduh pada tanggal 30 Maret 2019, pada pukul 20.11 WIB.

Sugiyono. (2018). Metode Penelitian Pendidikan. Bandung: Alfabeta.

Sukmadinata, N. S. (2016). Metode Penelitian Pendidikan. Bandung: Remaja Rosda Karya.

Wulandari, Nisa. (2016). "Analisis Kemampuan Literasi Sains Pada Aspek Pengetahuan dan Kompetensi Sains Siswa SMP pada Materi Kalor". www.jurnal.uinjkt.ac.id, diunduh pada tanggal 20 Maret 2019, pada pukul 16.00 WIB.

Stark, S., \& Torrance, H. (2005). Case study. In B. Somekh \& C. Lewin (Eds.), Research methods in the social sciences (hal. 3340). London: SAGE Publications Ltd.

Wang, J., Odell, S. J., Klecka, C. L., Spalding, E., \& Lin, E. (2010). Understanding teacher education reform. Journal of Teacher Education, 61(5), 395-402. 